
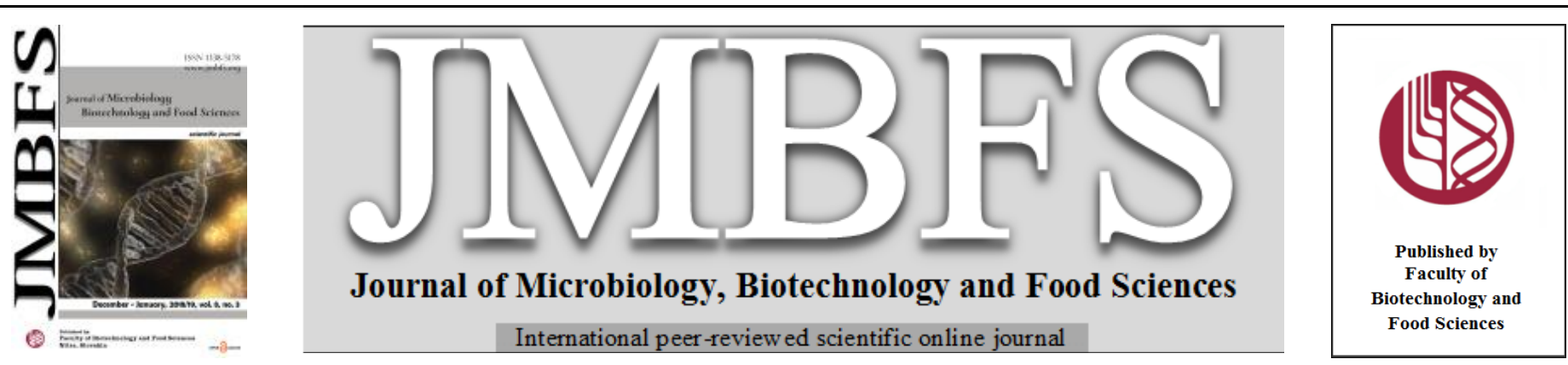

\title{
AROMATIC PROFILE OF RED WINES FROM GRAPEVINE VARIETIES RUBIN, STORGOZIA, BOUQUET, TRAPEZITSA, KAYLASHKY RUBIN AND PINOT NOIR, CULTIVATED IN THE REGION OF CENTRAL NORTHERN BULGARIA
}

\section{Dimitar Dimitrov*, Vanyo Haygarov, Tatyana Yoncheva}

$\operatorname{Address(es):~}$

Department of Enology and Chemistry, Institute of Viticulture and Enology, 1 Kala Tepe str., 5800, Pleven, Bulgaria.

*Corresponding author: dimitar robertov@abv.bg

doi: 10.15414/jmbfs.2018-19.8.3.885-889

ARTICLE INFO

Received 2. 7. 2018

Revised 21.9. 2018

Accepted 24. 9. 2018

Published 1. 12. 2018

Regular article open $\mathcal{O}$ access

\begin{abstract}
The objective of this study was to determine the aromatic profile of red wines obtained from Rubin, Storgozia, Bouquet, Trapezitsa, Kaylashky Rubin and Pinot Noir varieties from the region of Central Northern Bulgaria. First five varieties are hybrids selected in the Institute of Viticulture and Enology (IVE). Pinot Noir was used for control. GC-FID study for determination of the aromatic profile of red wines from proposed varieties was conducted. Twenty four volatile compounds were identified: 9 esters, 8 higher alcohols, 1 aldehyde, 5 terpene alcohols. The presence of methyl alcohol in all wines were found. Its concentrations were normal for red wines. The highest total content of volatile compounds was found in the wine from Kailashky Rubin variety $\left(693.97 \mathrm{mg} . \mathrm{dm}^{-3}\right)$. The ester fraction was dominated by ethyl acetate. The highest total ester content was found in the wine from Pinot Noir variety $\left(204.08 \mathrm{mg}^{-\mathrm{dm}^{-3}}\right)$. It was followed by the wine from Bouquet variety $\left(195.75 \mathrm{mg} \cdot \mathrm{dm}^{-3}\right)$. Acetaldehyde was the major established aldehyde. It was found in the largest quantity in the wine from Trapezitsa variety $\left(87.44 \mathrm{mg} . \mathrm{dm}^{-3}\right) .2$-methyl-1-butanol (active amyl alcohol) and 3-methyl-1-butanol (isoamyl alcohol) were found in the highest content from the higher alcohols fraction. The highest total content of higher alcohols was found in the wine from Rubin variety $\left(379.38 \mathrm{mg} \cdot \mathrm{dm}^{-3}\right)$. Five terpene alcohols were identified in the wines. Geraniol was presented in all examined wines. An extensive aromatic characterization by gas chromatographic analysis of red wines obtained from grapevine varieties selected in the Republic of Bulgaria was carried out. The research proves that the red wines obtained in the conditions of Central Northern Bulgaria were characterized by a complex aromatic composition due to the presence of different esters, higher alcohols and terpenes.
\end{abstract}

Keywords: Red wines, esters, higher alcohols, aldehydes, terpene alcohols, aromatic profile, methanol, grapevine varieties

\section{INTRODUCTION}

Over 800 volatile compounds have been identified in the wine $(\mathbf{L i}, \mathbf{2 0 0 6})$ Different quantitative variations of individual volatile compounds - tens to hundreds of mg.dm ${ }^{-3}$, as well as very low concentration ranges - $\mu \mathrm{g} \cdot \mathrm{dm}^{-3}$ to ng.dm ${ }^{-3}$ have been established (Rapp and Manderey, 1986; Li, 2006; SanchezPalomo et al., 2007). The total content of aromatic components in the wine can reach $800.00 \mathrm{mg} \cdot \mathrm{dm}^{-3}$ and more $-1200.00 \mathrm{mg} \cdot \mathrm{dm}^{-3}$ (Lakatošová et al., 2013) The volatile composition of the wine is variable, because it is dependent on many different and diverse factors: Genetic contribution of the grapevine variety - its ability to accumulate compounds with a strong aromatic effect in grapes, passing through the wine (Abrasheva et al., 2008; Gonzalez-Barreiro et al., 2013); Climatic conditions and soils in the geographical location where the grapevine variety is grown (Mira de Orduna, 2010; Dal Santo et al., 2013); The degree of grapes maturity (Robinson et al., 2014); The impact of applied agro-technical measures (Bureau et al., 2000); The direct influence of irrigation events induction and influence of water stress (Oliveira et al., 2003; Grimplet et al., 2007; Ou et al., 2010); The phytosanitary status of the vine - influence of fungal infections caused by Botrytis cinerea (Scoch et al., 1991) and Aspergillus niger (Winterhalter and Skouroumounis, 1997; Sefton and Williams, 1991); Technical and technological conditions of vinification (Oliveira et al., 2006); Metabolic activity of yeasts carrying the alcoholic fermentation (RodriguezBencomo et al., 2002) and lactic acid bacteria carrying the malolactic fermentation (Chobanova, 2012); The wine aging (Câmara et al., 2006; Meng et al., 2011).

The most important volatile compounds, which reflect the wine general aromatic profile, belong to the groups - esters, aldehydes, higher alcohols, terpene compounds (Lambrechts and Pretorius, 2000; Vilanova et al., 2013; Robinson et al., 2014).

The main and essential role of the esters is due to their large quantitative presence (Mason and Dufour, 2000) as well as to the rich variety of aromatic nuances that they give: the aroma of red and black berries (Pineau et al., 2009), honey aroma (Escudero et al., 2007), general fruit character of the wine (Li et al., 2008) and others.

The main quantitative and species esters diversity is a product of the winemaking process and related technological practices. The contribution of the grapevine to the final ester composition of the wine is very small, because only about $10.00-30.00 \mathrm{mg} \cdot \mathrm{dm}^{-3}$ of total esters are accumulated in the grapes (Abrasheva et al., 2008). The esters are formed in the wine by biological and chemical mechanisms. The biological is related to the yeasts vital activity (Chobanova, 2012). The other microflora may also have an impact (Swiegers $\boldsymbol{e t}$ al., 2005). Chemical formation is due to the esterification process - interaction between wine acids and alcohols (Chobanova, 2012). This formation mechanism takes place throughout the wine aging period and it is important for the "bouquet" of old wines (Yankov et al., 2000).

The ester content of young wines ranges from 50.00 to $250.00 \mathrm{mg} \cdot \mathrm{dm}^{-3}$ (Abrasheva et al., 2008) and may reach $500.00 \mathrm{mg} . \mathrm{dm}^{-3}$ (Chobanova, 2012). In the aging process, the ester content may reach $792.00-880.00 \mathrm{mg}^{-\mathrm{dm}^{-3}}$ (Yankov et al., 2000). The main, predominantly quantitative ester is ethyl acetate.

The higher alcohols are derived from the Saccharomyces cerevisiae yeasts metabolism (Bell and Henschke, 2005) producing $\alpha$-ketoacid precursors. Also, by the ability of yeasts to decompose the amino acids directly by the Elrich path (Etievant, 1991; Swiegers et al., 2005). The higher alcohols are characterized with a high threshold of aromatic perception. This is an indicator of their less direct impact on the wine aromatic profile. However, they have an indirect influence on the wine aroma. It is due to their participation in the process of esterification. By their interaction with acids, a wide variety of esters are formed, which complicates and improves the aroma of wines during the aging process (Meng et al., 2011). Their quantitative variation in wine ranges from 150.00 $550.00 \mathrm{mg} . \mathrm{dm}^{-3}$ (Abrasheva et al., 2008). In red wines, their content may reach $600.00 \mathrm{mg} \cdot \mathrm{dm}^{-3}$ (Chobanova, 2012). When they exceed these concentrations, their contribution to the general flavor becomes negative (Simpson, 1979). The 
exception to this thesis is only 2-phenylethanol (phenylethyl alcohol) (Lopez et al., 2003). It gives the rose aroma (Simpson, 1979).

The group of aldehydes is represented mainly by acetaldehyde. Its optimal quantities ranges from $10.00-110.00 \mathrm{mg} . \mathrm{dm}^{-3}$, but may reach $200.00 \mathrm{mg} . \mathrm{dm}^{-3}$ in dry wines (Chobanova, 2012). The acetaldehyde is an important component of the aromatic wine profile. It is produced by the yeasts Saccharomyces cerevisiae during fermentation. When it is available in its optimal quantities in dry wines, it gives a pleasant apple aroma, but when exceeding them it produces an oxidized tone in the wine (Chobanova, 2012).

An important component of the aromatic composition are terpenic compounds. Of these, the terpenic alcohols linalool, $\alpha$-terpineol, $\beta$-citronellol, nerol and geraniol (Arrhaenius et al., 1996; Luan et al., 2006; Oliveira et al., 2008) are found in wines. They are the product of the grapevine metabolism from where they accumulate in the grapes (Manito, 1980). They are primarily responsible for the aroma of wines obtained from muscat varieties (Vilanova et al., 2013).

The objective of this study is to determine the aromatic profile of red wines obtained from Rubin, Storgozia, Bouquet, Trapezitsa, Kaylashky Rubin and Pinot Noir varieties from the region of Central Northern Bulgaria.

\section{MATERIAL AND METHODS}

\section{Grape varieties and vinification}

The study was conducted at the Institute of Viticulture and Enology (IVE) Pleven in the period 2017-2018. The object of the present study were red wines, obtained from Rubin, Storgozia, Bouquet, Trapezitsa, Kaylashky Rubin and Pinot Noir grape varieties, harvested in 2017, cultivated in the region of Pleven, Central Northern Bulgaria. The first five varieties were selected in IVE, interand intra-species hybrids. The latter being widespread introduced variety from Vitis vinifera. The parental forms of the selected hybrids were as follows:

- Rubin - Nebiolo x Shiraz (Petkov, 1977)

- Storgozia - Bouquet x Villar Blanc (Katerov et al., 1990)

- Bouquet - Mavrud x Pinot noir (Petkov, 1977)

- Trapezitsa - Danube Gamza x Marseilles early (Ivanov, 2016)

- Kaylashky Rubin - (Pamid x Hybrid VI 2/15) x (Gamma noir x Vitis amurensis) (Ivanov, 2016)

The experimental vineyards on an area of 0.2 ha for each variety were grown in the Experimental Base of IVE.

The grapes from the different varieties were harvested (30 kg for each variety) and were vinified at the Experimental Wine Cellar of IVE. A classic scheme for the production of dry red wines (Yankov et al., 1992) was applied - crushing and destemming, sulphitation $(50 \mathrm{mg} / \mathrm{kg} \mathrm{SO}$ ), inoculating with pure culture dry yeasts Saccharomyces cerevisiae Vitilevure CSM - 20 g. $100 \mathrm{dm}^{-3}$, temperature of fermentation $-28^{\circ} \mathrm{C}$, separation from solids, further sulphitation, storage.

\section{Determination of alcohol content of obtained wines}

The alcohol content of the obtained wines was defined by specialized equipment with high precision - automatic distillation unit - Gibertiny BEE RV 10326 (Gibertiny Electronics Srl., Milano, Italy) and Gibertiny Densi Mat CE AM 148 (Gibertiny Electronics Srl., Milano, Italy).

\section{Aromatic content determination by Gas Chromatography (Gas Chromatograph with Flame Ionization Detector)}

Gas chromatographic determination of the aromatic components in wine distillates was done. The content of major volatile aromatic compounds was determined on the basis of stock standard solution prepared in accordance with the IS method 3752:2005. The method describes the preparation of standard solution with one congener, but the step of preparation was followed for the preparation of a solution with more compounds. The standard solution in this study include the following compounds (purity > 99.0\%): acetaldehyde, ethy acetate, methanol, isopropyl acetate, 1-propanol, 2-butanol, propyl acetate, 2methyl-propanol, isobutanol, 1-butanol, isobutyl acetate, ethyl butyrate, butyl acetate, 2-methyl-1-butanol, 3-methyl-1-butanol, ethyl isovalerate, 1-pentanol, pentyl acetate, 1-hexanol, ethyl hexanoate, hexyl acetate, 1-heptanol, linalool oxide, phenyl acetate, ethyl caprylate, $\alpha$-terpineol, $\beta$-citronellol, nerol, geraniol. As an internal standard 1-octanol was used.

The $2 \mu \mathrm{l}$ of prepared standard solution was injected in gas chromatograph Varian 3900 (Varian Analytical Instruments, Walnut Creek, California, USA) with a capillary column VF max MS (30 m, $0.25 \mathrm{~mm} \mathrm{ID,} \mathrm{DF}=0.25 \mu \mathrm{m})$, equipped with a flame ionization detector (FID). The used carrier gas was Helium. Hydrogen to support combustion was supplied to the chromatograph via a hydrogen bottle. The injection is manually by microsyringe.

The parameters of the gas chromatographic determination were: injector temperature $-220{ }^{\circ} \mathrm{C}$; detector temperature $-250{ }^{\circ} \mathrm{C}$, initial oven temperature $35{ }^{\circ} \mathrm{C}$ for $1 \mathrm{~min}$, up to $55^{\circ} \mathrm{C}$ with step of $2{ }^{\circ} \mathrm{C} / \mathrm{min}$ for $11 \mathrm{~min}$, up to $230{ }^{\circ} \mathrm{C}$ with step of $15^{\circ} \mathrm{C} / \mathrm{min}$ for $3 \mathrm{~min}$. Total time of chromatography analysis $-25.67 \mathrm{~min}$. After determination of the retention times: acetaldehyde (3.256), ethyl acetate (4.017), methanol (4.186), isopropyl acetate (5.897), 1-propanol (6.763), 2- butanol (7.215), propyl acetate (7.427), 2-methyl-propanol (7.665), isobutano (7.921), 1-butanol (8.473), isobutyl acetate (8.675), ethyl butyrate (9.868), butyl acetate (12.277), 2-methyl-1-butanol (13.408), 3-methyl-1-butanol (13.542), ethyl isovalerate (13.589), 1-pentanol (14.192), pentyl acetate (14.273), 1hexanol (15.621), ethyl hexanoate (16.410), hexyl acetate (16.677), 1-heptanol (16.727), linalool oxide (16.981), phenyl acetate (18.400), ethyl caprylate (18.949), $\alpha$-terpineol (19.387), $\beta$-citronellol (19.691), nerol (20.022), geranio (20.730) of aromatic compounds in the standard solution the identification and quantification of the volatile aromatic substances in the wines was established The aromatic composition was determined based on injection of wine distillates Prepared samples were injected in a gas chromatograph and was carried out an identification and quantification of the aromatic substances in each of them

\section{RESULTS AND DISCUSSION}

The results for the volatile composition of the examined red wines are presented in Table 1.

The chromatographic profiles of the examined red wines from the studied varieties are presented in Figures $1-6$

The total amount of identified volatile compounds was found to be in the range of $404.79 \mathrm{mg} \cdot \mathrm{dm}^{-3}$ (Pinot Noir) - $693.97 \mathrm{mg} \cdot \mathrm{dm}^{-3}$ (Kaylashky Rubin). This content corresponds to the typical quantity of total volatile composition of young wines. The data are correlated with the finding of Lakatošová et al. (2013) (total volatile components content up to $800 \mathrm{mg} \cdot \mathrm{dm}^{-3}$ ). Quantitative prevalence was observed in the wine from Kaylashky Rubin variety.

The esters, as a group with a fundamental contribution to the wine general aromatic perception, were represented by 9 identified compounds. Quantitative dominance for total ester content in wine from Pinot Noir variety $(204.08 \mathrm{mg} . \mathrm{dm}$ ${ }^{3}$ ) was established, followed by the wine from Bouquet grape variety (195.75 mg.dm ${ }^{-3}$ ). The lowest total ester content was found in the wine from Rubin variety $\left(57.63 \mathrm{mg} \cdot \mathrm{dm}^{-3}\right)$

The content of esters in the studied wines is typical for young red wines and correlates with the ranges of variation presented by Abrasheva et al. (2008).

Ethyl acetate, which is a major component of the ester composition, was established in all studied wines. Its highest content was established in the wine from Bouquet variety $\left(55.44 \mathrm{mg} \cdot \mathrm{dm}^{-3}\right)$. The lowest content was found in the wine from Kaylashky Rubin variety $\left(25.34 \mathrm{mg} . \mathrm{dm}^{-3}\right)$. The limit concentration at which ethyl acetate exerts a positive influence on the wine fruit flavor is $150.00 \mathrm{mg} . \mathrm{dm}^{-3}$ (Tao and Li, 2009). When the ester is present in concentrations of $50.00-60.00$ mg.dm ${ }^{-3}$, its aromatic effect is positive (Abrasheva et al., 2008). At concentrations exceeding the threshold values, it deteriorates the quality of the wines, giving an acetic-acid aromatic-flavor perception (Gil et al., 2006).

The ethyl acetate concentrations, found in this study, not exceed the thresholds This determines the positive influence of the ester on the total wine flavor.

Ethyl butyrate was found in two wines - the wine from Rubin variety (18.61 mg.dm ${ }^{-3}$ ) and the wine from Trapezitsa $\left(12.93 \mathrm{mg} \cdot \mathrm{dm}^{-3}\right)$. This ester was found in Cabernet Sauvignon wine from China, where it gives a berry fruit taste (Tao and Li, 2009).

Phenyl acetate has been identified in almost all samples except for wine from Trapezitsa variety. The sensory impact of this ester is associated with banana and apple aroma (Ivanova et al., 2013).

The aldehyde fraction was represented by its principal component - acetaldehyde. Its content in the wine from Trapezitsa variety $\left(87.44 \mathrm{mg} . \mathrm{dm}^{-3}\right)$ was the highest. The lowest concentration was found in the wine from Kaylashky Rubin variety $\left(17.19 \mathrm{mg} \cdot \mathrm{dm}^{-3}\right)$. The established levels correlate with the ranges of its normal presence.

The higher alcohols are a significant fraction of the wine flavor profile. The highest total concentration of higher alcohols was found in the wine from Rubin variety $\left(379.36 \mathrm{mg} \cdot \mathrm{dm}^{-3}\right)$, followed by that from the Kaylashky Rubin variety $\left(329.18 \mathrm{mg} \cdot \mathrm{dm}^{-3}\right)$. The lowest total content of higher alcohols in wine from Pinot Noir variety $\left(61.34 \mathrm{mg} . \mathrm{dm}^{-3}\right)$ was established. 8 higher alcohols were identified in the wines. The presence of 2-methyl-1-butanol (active amyl alcohol) and 3 methyl-1-butanol (isoamyl alcohol) was predominantly. The first was found in absolutely all analyzed wines. It was established at the highest concentration in the wine from Rubin variety $\left(373.02 \mathrm{mg} \cdot \mathrm{dm}^{-3}\right)$. The lowest content of 2 -methyl1-butanol in wine from Trapezitsa variety $\left(43.41 \mathrm{mg}^{-\mathrm{dm}^{-3}}\right)$ was found. Cellamare et al. (2009) conducted a study on the effect of light on the composition of some volatile components in wines. They found the presence of 2-methyl-1-butanol only in the red wine at $800.00 \mathrm{mg} \cdot \mathrm{dm}^{-3}$. The concentrations of this compound found in our study are within the range of the observed amount of Cellamare $\boldsymbol{e t}$ al. (2009).

3-methyl-1-butanol (isoamyl alcohol) was not found only in the wines from Rubin and Pinot Noir varieties. In the other wines, it ranged from $115.40 \mathrm{mg} . \mathrm{dm}^{-3}$ (Trapezitsa) to 190.95 mg.dm ${ }^{-3}$ (Kaylashky Rubin). The results for this alcohol are in correlation with the range of its variation $\left(200.00-500.00 \mathrm{mg} \cdot \mathrm{dm}^{-3}\right)$ indicated by Chobanova (2012).

All wines have been found to contain 1-hexanol. In four of the wines (respectively from varieties Storgozia, Bouquet, Trapezitsa and Pinot Noir) it was present in traces. Its normal concentration should be within $4.00-10.00 \mathrm{mg} . \mathrm{dm}^{-3}$ and gives a herbaceous taste (Chobanova, 2012). In wine from the Rubin 
variety, it was found to be in normal concentration $\left(6.64 \mathrm{mg} \cdot \mathrm{dm}^{-3}\right)$, but in the wine from Kaylashky Rubin variety $\left(15.48 \mathrm{mg} \cdot \mathrm{dm}^{-3}\right)$ its quantity exceeds the threshold.

The terpenic wine profile was represented by 5 identified terpene alcohols. The highest total terpenic content was found in the wine from Trapezitsa $(1.66$ mg.dm $\left.{ }^{-3}\right)$. The lowest was the content in the wine from Pinot Noir variety $(0.27$ $\left.\mathrm{mg} \cdot \mathrm{dm}^{-3}\right)$. Geraniol was practically found in all wines.

The presence of a substance that is not a part of the aromatic matrix but found to be a normal component of the volatile composition in red wines - methanol was established. Its presence is due to its precursor - pectin present in the fruit, which is degraded by the pectolytic enzyme complex of the grapes (Marinov, 2005) The normal limited content of methyl alcohol in red wines should be in the range of 36.00 - $350.00 \mathrm{mg} . \mathrm{dm}^{-3}$ (according to Chobanova, 2012) or 60.00 - 230.00 mg.dm ${ }^{-3}$ (according to Abrasheva et al., 2008). The methyl alcohol must not exceed these amounts. In the present study, methanol was found at the lowest content in wine from Bouquet variety $\left(87.27 \mathrm{mg} \cdot \mathrm{dm}^{-3}\right)$, and the highest in the wine from Kaylashky Rubin $\left(235.71{\mathrm{mg} . \mathrm{dm}^{-3}}^{-3}\right.$. The data are in agreement with the permitted thresholds of content for this alcohol in red wines.

Table 1 Content of volatile aromatic compounds in red wines from Rubin, Storgozia, Bouquet, Trapezitsa, Kaylashky Rubin and Pinot Noir grapevine varieties

\begin{tabular}{|c|c|c|c|c|c|c|}
\hline \multirow[b]{2}{*}{ IDENTIFIED COMPOUNDS, mg.dm ${ }^{-3}$} & \multicolumn{6}{|c|}{ WINES } \\
\hline & RUBIN & STORGOZIA & BOUQUET & TRAPEZITSA & $\begin{array}{c}\text { KAYLASHKY } \\
\text { RUBIN }\end{array}$ & PINOT NOIR \\
\hline Acetaldehyde & 33.76 & 24.12 & 26.16 & 87.44 & 17.19 & 22.83 \\
\hline Methanol & 110.03 & 141.95 & 87.27 & 228.88 & 235.71 & 116.27 \\
\hline \multicolumn{7}{|l|}{ 1. Higher alcohols } \\
\hline 1-propanol & $\mathrm{ND}$ & ND & $\mathrm{ND}$ & ND & ND & 0.05 \\
\hline 2-butanol & 0.05 & 0.05 & 14.23 & ND & 10.51 & 13.04 \\
\hline 2-methyl-1-butanol & 373.02 & 74.02 & 86.81 & 43.41 & 112.34 & 48.15 \\
\hline 3-methyl-1-butanol & ND & 173.18 & 186.58 & 115.14 & 190.95 & ND \\
\hline 2-methyl-1-propanol & ND & ND & $\mathrm{ND}$ & 39.67 & ND & ND \\
\hline 1-pentanol & 0.05 & 0.05 & 0.05 & ND & ND & 0.05 \\
\hline 1-hexanol & 6.64 & 0.05 & 0.05 & 0.05 & 15.48 & 0.05 \\
\hline 1-heptanol & ND & $\mathrm{ND}$ & 0.05 & ND & ND & ND \\
\hline Total higher alcohols & 379.76 & 247.35 & 287.77 & 198.27 & 329.28 & 61.34 \\
\hline \multicolumn{7}{|l|}{ 2. Esters } \\
\hline Ethyl acetate & 30.03 & 30.92 & 55.44 & 46.15 & 25.34 & 41.74 \\
\hline Isopropyl acetate & 0.05 & ND & 0.05 & ND & 0.05 & ND \\
\hline Isobutyl acetate & ND & 88.96 & 120.90 & ND & 82.82 & 162.29 \\
\hline Ethyl butyrate & 18.61 & ND & ND & 12.93 & $\mathrm{ND}$ & ND \\
\hline Ethyl hexanoate & ND & ND & 0.05 & ND & 0.05 & ND \\
\hline Ethyl isovalerate & ND & 0.05 & $\mathrm{ND}$ & $\mathrm{ND}$ & ND & $\mathrm{ND}$ \\
\hline Pentyl acetate & $\mathrm{ND}$ & 25.27 & 13.63 & 0.05 & ND & $\mathrm{ND}$ \\
\hline Phenyl acetate & 0.05 & 0.05 & 5.68 & $\mathrm{ND}$ & 2.40 & 0.05 \\
\hline Ethyl caprylate & 8.89 & 0.05 & ND & 28.15 & ND & ND \\
\hline Total esters & 57.63 & 145.30 & 195.75 & 87.28 & 110.66 & 204.08 \\
\hline \multicolumn{7}{|l|}{ 3. Terpenes } \\
\hline$\alpha-$ terpineol & $\mathrm{ND}$ & 0.05 & 0.09 & 0.57 & ND & 0.05 \\
\hline Linalool oxide & ND & ND & 0.05 & 0.05 & ND & ND \\
\hline Nerol & 0.09 & 0.05 & 0.05 & 0.87 & 0.11 & 0.05 \\
\hline$\beta$ - citronellol & 0.14 & 0.09 & 0.05 & ND & 0.074 & 0.015 \\
\hline Geraniol & 0.97 & 0.31 & 0.54 & 0.17 & 0.95 & 0.16 \\
\hline Total terpenes & 1.20 & 0.50 & 0.78 & 1.66 & 1.13 & 0.27 \\
\hline TOTAL VOLATILE CONTENT & 582.38 & 559.22 & 597.73 & 603.53 & 693.97 & 404.79 \\
\hline
\end{tabular}

*ND - Not Detected

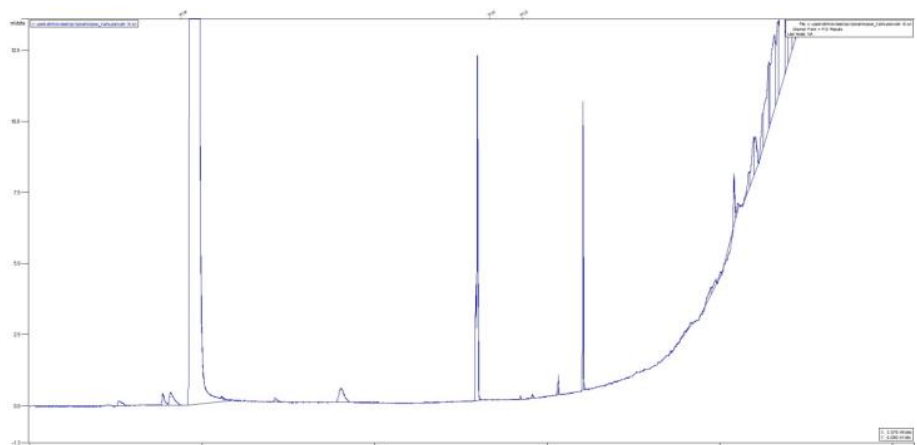

Figure 1 Chromatographic profile of red wine from Rubin variety

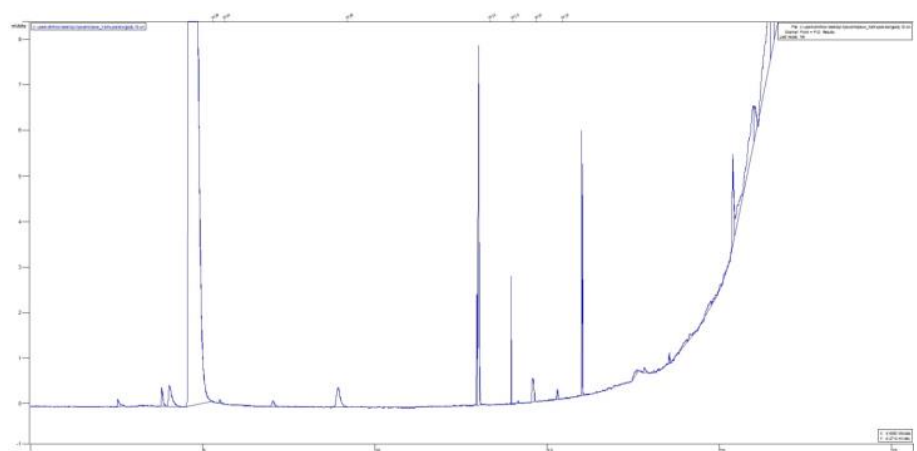

Figure 2 Chromatographic profile of red wine from Storgozia variety 


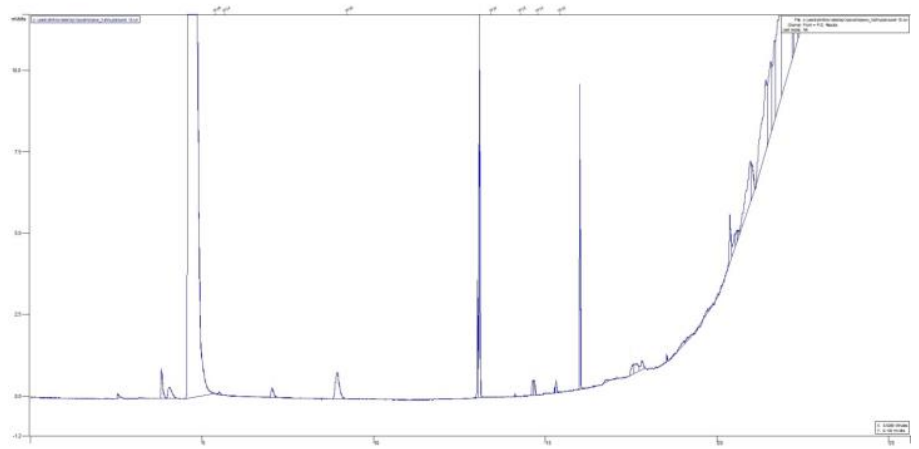

Figure 3 Chromatographic profile of red wine from Bouquet variety

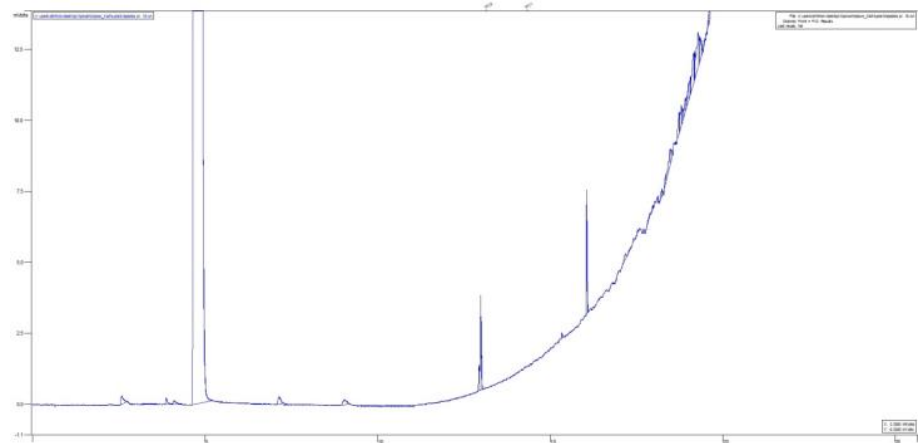

Figure 4 Chromatographic profile of red wine from Trapezitsa variety

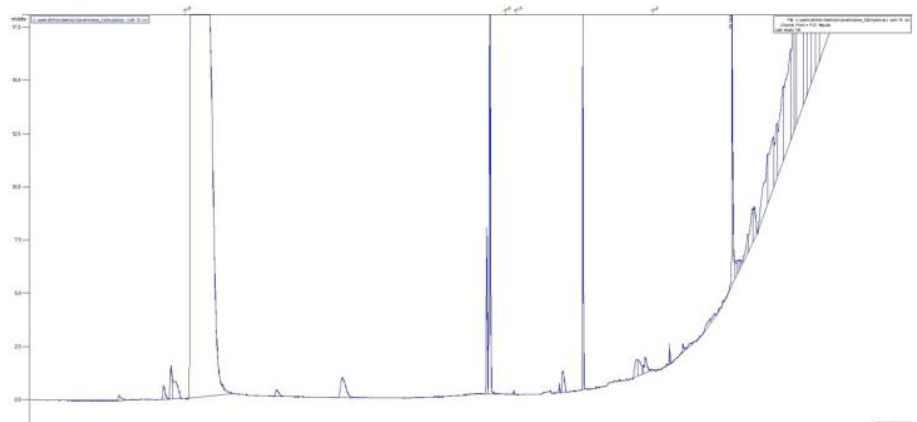

Figure 5 Chromatographic profile of red wine from Kaylashky Rubin variety

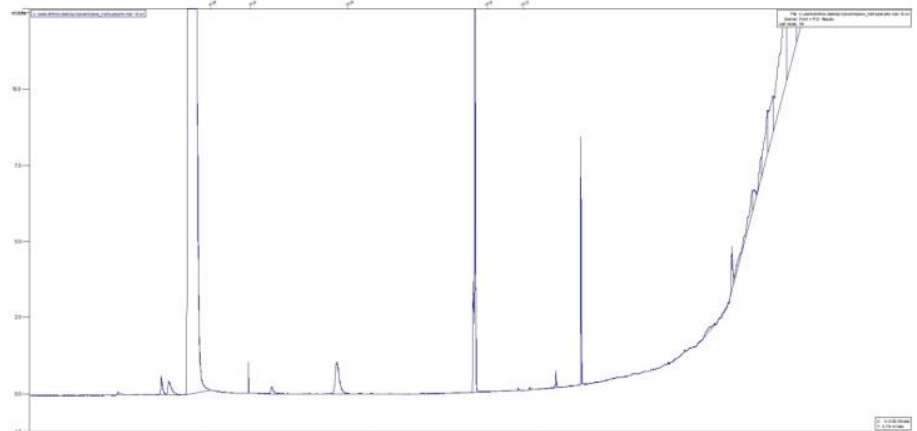

Figure 6 Chromatographic profile of red wine from Pinot noir variety

\section{CONCLUSION}

The aromatic profile of red wines from Rubin, Storgozia, Bouquet, Trapezitsa, Kaylashky Rubin and Pinot Noir varieties from the region of Pleven, Central Northern Bulgaria was determined.

Various aromatic components from the groups of esters, higher alcohols, aldehydes, terpene alcohols, present in red wines, were identified and quantified. With the highest total amount of volatile compounds, the wine from Kaylashky Rubin hybrid variety $\left(693.91 \mathrm{mg} . \mathrm{dm}^{-3}\right)$ was distinguished.

The ester composition of the wines was determined. Nine esters were identified and quantified. Ethyl acetate was predominant. The highest total ester content in the wine from Pinot Noir variety $\left(204.08 \mathrm{mg} / \mathrm{dm}^{3}\right)$ was established.

The aromatic composition includes 8 higher alcohols. Of these two - 2-methyl-1butanol (active amyl alcohol) and 3-methyl-1-butanol (isoamyl alcohol) were quantitatively dominant. The highest total content of higher alcohols was found in wine from Rubin variety $\left(379.36 \mathrm{mg} / \mathrm{dm}^{3}\right)$, followed by Kaylashky Rubin $\left(329.18 \mathrm{mg} / \mathrm{dm}^{3}\right)$.

Five terpenes have been identified. Geraniol was present in all tested wines.

Methyl alcohol was found in all wines. Its concentrations were typical for red wines.

An extensive aromatic characterization by gas chromatographic analysis of red wines obtained from grapevine varieties selected in the Republic of Bulgaria was carried out. The research proved that the red wines obtained in the conditions of Central Northern Bulgaria were characterized by a complex aromatic composition, due to the presence of different esters, higher alcohols and terpenes.

\section{REFERENCES}

ABRASHEVA, P., BAMBALOV, K., GEORGIEV, A. 2008. Viticulture and Enology. Editor "Matkom", Sofia, Bulgaria, p: 344 (BG).

ARRHENIUS, S., MCCLOSKEY, L., SYLVAN, M. 1996. Chemical markers for aroma of Vitis vinifera var. Chardonnay regional wines. Journal of Agriculture and Food Chemistry, 44:1085-1090. https://doi.org/10.1021/if9505943

BELL, S., HENSCHKE, P. 2005. Implications of nitrogen nutrition for grapes, fermentation and wine. Australian Journal of Grape and Wine Research, 11:242 295. https://doi.org/10.1111/j.1755-0238.2005.tb00028.x

BUREAU, S., BAUMES, R, RAZUNGLES, A. 2000. Effects of vine or bunch shading on the glycosylated flavor precursors in grapes of Vitis vinifera L. cv. Syrah. Journal of Agriculture and Food Chemistry, 48:1290-1297. https://doi.org/10.1021/if990507x

CÂMARA, J., ALVES, M., MARQUES, J. 2006. Changes in volatile composition of Madeira wines during their oxidative ageing. Analytica Chimica Acta, 563(1-2):188-197. https://doi.org/10.1016/i.aca.2005.10.031

CELLAMARE, L., D'AURIA, M., EMANUELE, L., RACIOPPI, R. 2009. The effect of light on the composition of some volatile compounds in wine: an HSSPME-GC-MS study. International Journal of Food Science and Technology, 44:2377 - 2384. https://doi.org/10.1111/j.1365-2621.2008.01723.x

CHOBANOVA, D., 2012. Enology. Part I: Composition of wine. Academic Press of University of Food Technologies, Plovdiv (BG).

DAL SANTO, S., TORNIELLI, G., ZENONI, S., FASOLI, M., FARINA, L. ANESI, A., GUZZO, F., DELlEDONNE, M., PEZZOTTI, M. 2013. The plasticity of the grapevine berry transcriptome. Genome Biology, 14:R54. https://doi.org/10.1186/gb-2013-14-6-r54

ESCUDERO, A., CAMPO, E., FARIÑA, L., CACHO, J., FERREIRA, V. 2007 Analytical characterization of the aroma of five premium red wines. Insights into the role of odor families and the concept of fruitiness of wines. Journal of Agriculture and Food Chemistry, 55: 4501-4510 https://doi.org/10.1021/jf0636418

ETIEVANT, P.X. 1991. Volatile compounds of food and beverages. In: Maarse, H. (ed). Dekker, New York. p: 546.

GIL, M., CABELKIS, J., ARRAYS, T., PRODANOV, M. 2006 Characterization of the volatile fraction of young wines from the Denomination of origin "Vinos de Madrid (Spain)". Analytica Chimica Acta, 563: 145 - 153 https://doi.org/10.1016/i.aca.2005.11.060

GONZÁLEZ-BARREIRO, C., RIAL-OTERO, R., CANCHO-GRANDE, B., SIMAL-GÁNDARA, J. 2013. Wine aroma compounds in grapes: A critical review. Critical Reviews in Food Science and Nutrition. https://doi.org/10.1080/10408398.2011.650336

GRIMPLET, J., DELUC, L., TILLET, R., WHEATLEY, M., SCHLAUCH, K. CRAMER, G., CUSHMAN, J. 2007. Tissue-specific mRNA expression profiling in grape berry tissues. BMC Genomics, 8:187. https://doi.org/10.1186/1471 2164-8-187

IVANOV, M. 2016. Hybridization in the vine selection. Monography. Academic Publishing of Agricultural University, Plovdiv (BG).

IVANOVA, V., STEFOVA, M., VOJNOSKI, B., STAFILOV, T., BÍRÓ, I., BUFA, A., FELINGER, A., KILAR, F. 2013. Volatile Composition of Macedonian and Hungarian Wines Assessed by GC/MS. Food and Bioprocess Technology, 6:1609-1617. https://doi.org/10.1007/s11947-011-0760-y

KATEROV, K., DONCHEV, A., KONDAREV, M., GETOV, G., NACHEV, T., HERSHKOVICH, E., VALCHEV, V., MARKOVA, M., BRAYKOV, D., TODOROV, H., MAMAROV, P., IVANOV, Y., ZANKOV, Z., CANKOV, B. RADULOV, L., IVANOV, M., Jekova, M. 1990. Bulgarian Ampelography, Volume I. Publishing House of the Bulgarian Academy of Sciences (BG).

LAKATOŠOVÁ, J., PRIESOLOVÁ, L., DOKUPILOVÁ, I., ŠMOGROVIČOVÁ, D. 2013. Characterisation of Slovak varietal wine aroma compounds by gas chromatography mass spectrometry. Potravinarstvo, 7 Special Issue : 180-182.

LAMBRECHTS, M., PRETORIUS, I. 2000. Yeast and its Importance to Wine Aroma - A Review. South African Journal of Enology and Viticulture, 21:Specia Issue.

LI, H. 2006. Wine tasting. China Science Press, Beijing, China

LI, H., TAO, Y., WANG, H., ZHANG, L. 2008. Impact odorants of Chardonnay dry white wine from Changli County (China). European Food Research and Technology, 227: 287-292. https://doi.org/10.1007/s00217-007-0722-9

LOPEZ, R., ORTIN, N., PEREZ-TRUJILLO, J., CACHO, J., FERREIRA, V. 2003. Impact odorants of different young white wines from the canary islands. 
Journal of Agricultural and Food Chemistry, 51: 3419-3425. https://doi.org/10.1021/if026045w

LUAN, F., MOSANDL, A., GUBESCH, M., MATTHIAS, M., WUST, M. 2006. Enantioselective analysis of monoterpenes in different grape varieties during berry ripening using stir bar sorptive extraction- and solid phase extractionenantioselective-multidimensional gas chromatography-mass spectrometry. Journal of Chromatography A., 1112:369-374. https://doi.org/10.1016/j.chroma.2005.12.056

MANITTO, P. 1980. Biosynthesis of natural products. Ellis Horwood, Chichester.

MARINOV, M. 2005. Technology of alcoholic beverages and spirits. Plovdiv, Bulgaria. Academic Publishing of University of Food Technologies. ISSN 0477 0250 (BG).

MASON, A., DUFOUR, J. 2000. Alcohol acetyltransferases and the significance of ester synthesis in yeast. Yeast, 16:1287-1298. https://doi.org/10.1002/10970061(200010)16:14<1287::aid-yea613>3.0.co;2-i

MENG, J., FANG, Y., GAO, J., ZHANG, A., LIU, J., GUO, Z., ZHANG, Z., LI, H. 2011. Changes in aromatic compounds of cabernet sauvignon wines during ageing in stainless steel tanks. African Journal of Biotechnology, 10 (55):1164011647.

MIRA DE ORDUÑA, R. 2010. Climate change associated effects on grape and wine quality and production. Food Research International, 43: 1844-1855. https://doi.org/10.1016/..foodres.2010.05.001

OLIVEIRA, J., FARIA, M., SA, F., BARROS, F., ARANJO, I. 2006. C6alcohols as varietal markers for assessment of wine origin. Analytica Chimica Acta, 563:300 - 309. https://doi.org/10.1016/j.aca.2005.12.029

OLIVEIRA, C., SILVA FERREIRA, A., MENDES PINTO, M., HOGG, T. ALVES, F., GUEDES DE PINHO, P. 2003. Carotenoid compounds in grapes and their relationship to plant water status. Journal of Agriculture and Food Chemistry, 51:5967-5971. https://doi.org/10.1021/if034275k

OLIVEIRA, J., OLIVEIRA, P., BAUMES, R., MAIA, M.O. 2008. Volatile and glycosidically bound composition of Loureiro and Alvarinho wines. Food Science and Technology International, 14: 341-353. https://doi.org/10.1177/1082013208097442

OU, C., DU, X., SHELlIE, K., ROSS, C., QIAN, M.C. 2010. Volatile compounds and sensory attirbutes of wine from cv. Merlot (Vitis vinifera $\mathrm{L}$.) grown under differential levels of water deficit with or without a kaolin-based foliar reflectant particle film. Journal of Agriculture and Food Chemistry, 58:12890-12898. https://doi.org/10.1021/if102587x

PETKOV, G. 1977. Biochemical and technological study of Bouchet, Ruen and Rubin grapevine varieties for production of red wines. PhD Thesis. Institute of Viticulture and Enology, Pleven (BG).

PINEAU, B., BARBE, J., VAN LEEUWEN, C., DUBOURDIEU, D. 2009. Examples of perceptive interactions involved in specific "red-" and "black-berry" aromas in red wines. Journal of Agriculture and Food Chemistry,57:3702-3708. https://doi.org/10.1021/if803325v

RAPP, A., MANDERY, H. 1986. Wine aroma. Experientia, 42:873-884. https://doi.org/10.1007/bf01941764

ROBINSON, A., BOSS, P., SOLOMON, P., TRENGOVE, R., HEYMANN, H., EBELER, S. 2014. Origins of grape and wine aroma. Part I. Chemical components and viticultural impacts. American Journal of Enology and Viticulture, 65(1):1-24. https://doi.org/10.5344/ajev.2013.12070

RODRÍGUEZ-BENCOMO, J., CONDE, J., RODRÍGUEZ-DELGADO, M., GARCÍA-MONTELONGO, F., PÉREZ-TRUJILLO, J. 2002. Determination of esters in dry and sweet white wines by headspace solid-phase microextraction and gas chromatography. Journal of Chromatography A., 963(1-2):213-223. https://doi.org/10.1016/s0021-9673(02)00551-4

SANCHEZ PALOMO, E., DIAZ-MAROTO, M., GONZALEZ VIÑAS, M. SORIANO-PÉREZ, A., PÉREZ-COELLO, M. 2007. Aroma profile of wines from Albillo and Muscat grape varieties at different stages of ripening. Food Chemistry, 18:398-403. https://doi.org/10.1016/i.foodcont.2005.11.006

SCHOCH, E., BENDA, I., SCHREIER, P. 1991. Bioconversion of $\alpha$-damascone by Botrytis cinerea. Appleid Environmental Microbiology, 57:15-18.

STANDARD 3752:2005. Alcohol Drinks - Methods of Test (Second Revision). SEFTON, M., WILLIAMS, P. 1991. Generation of oxidation artifacts during the hydrolysis of norisoprenoid glycosides by fungal enzyme preparations. Journal of Agriculture and Food Chemistry, 39:1994-1997. https://doi.org/10.1021/ff00011a023

SIMPSON, R. 1979. Some important aroma components of white wine. Food Technology in Australia, 31:516-522.

STANDARD 3752:2005. Alcohol Drinks - Methods of Test (Second Revision).

SWIEGERS, J., BARTOWSKY, E., HEMSCHKE, P., PRETORIUS, I. 2005a.

Yeast and bacterial modulation of wine aroma and flavour. Australian Journal of Grape and Wine Research, 11:139-173. https://doi.org/10.1111/j.1755 0238.2005.tb00285.x

TAO, Y., LI, H. 2009. Active volatiles of Cabernet Sauvignon wine from Changli County. Natural Science, 1:176-182. https://doi.org/10.4236/health.2009.13029 VILANOVA, M., GENISHEVA, Z., GRAÑA, M., OLIVEIRA, J.M. 2013 Determination of odorants in varietal wines from international grape cultivars (Vitis vinifera) grown in NW Spain. South African Journal of Enology and Viticulture, 34:212-222. https://doi.org/10.21548/34-2-1097
WINTERHALTER, P., SKOUROUMOUNIS, G. 1997. Glycoconjugated aroma compounds: Occurrence, role and biotechnological transformation. In Advances in Biochemical Engineering/Biotechnology. T. Scheper (ed.), pp. 73-105. Springer-Verlag, Berlin. https://doi.org/10.1007/bfb0102063

YANKOV, A., KUKUNOV, S., YANKOVA, T. 2000. Technology of wine and higher alcohol drinks. Publisher: Teodoros, Sofia, Bulgaria, p:193 (BG).

YANKOV, A. 1992. Winemaking Technology. Sofia, Zemizdat (BG). 